\title{
Developmental variation in DNA methylation in poplar (Populus trichocarpa)
}

\author{
Kelly Vining ${ }^{1}$, Kyle R Pomraning ${ }^{2}$, Larry Wilhelm${ }^{3}$, Henry D Priest ${ }^{3}$, Cathleen Ma', Ruoqing Zhu', \\ Elizabeth Etherington", Matteo Pellegrini ${ }^{4}$, Todd Mockler ${ }^{3}$, Michael Freitag ${ }^{5}$, Steven H Strauss ${ }^{6^{*}}$ \\ From IUFRO Tree Biotechnology Conference 2011: From Genomes to Integration and Delivery \\ Arraial d Ajuda, Bahia, Brazil. 26 June - 2 July 2011
}

Using methylated DNA immunoprecipitation followed by high-throughput sequencing (MeDIP-seq), we analyzed DNA methylation patterns in the $P$. trichocarpa genome in relation to four biological processes: bud dormancy and release, mature organ maintenance, in vitro organogenesis, and methylation suppression. Here, we report results from Illumina sequencing of nine sampled tissues, each representing 1 to 2 biological replicates. We sequenced $26 \mathrm{M}-97 \mathrm{M}$ reads per tissue type, and validated our MeDIP-seq results using bisulfite sequencing of selected targets.

Unique MeDIP-seq reads covered $\sim 30-60 \%$ of genome space at an average depth of 4 to 12 reads/nucleotide. Transposons and other repeat elements were enriched within the methylated fraction of the genome. The pattern of gene model methylation showed higher methylation at promoters, in the middle of coding regions, and 3 ' to ends of genes, similar to that observed in other plant and animal species. Numbers of methylated genes identified varied widely by tissue type.

We produced summary data for genome methylation in P. trichocarpa, including the distribution of methylation across chromosomes (Fig. 1) and in and around genes. The intensity of methylation was highly heterogeneous within and between chromosomes. One-third of the genome, analyzed as $1 \mathrm{~kb}$ tiled windows, was differentially methylated among tissues. An example of a chromosomal region with differential methylation is shown in Fig. 2. Promoter methylation was more frequent than gene body methylation. Male catkins differed from the other tissues in that gene body methylation was more prevalent than promoter methylation, and two

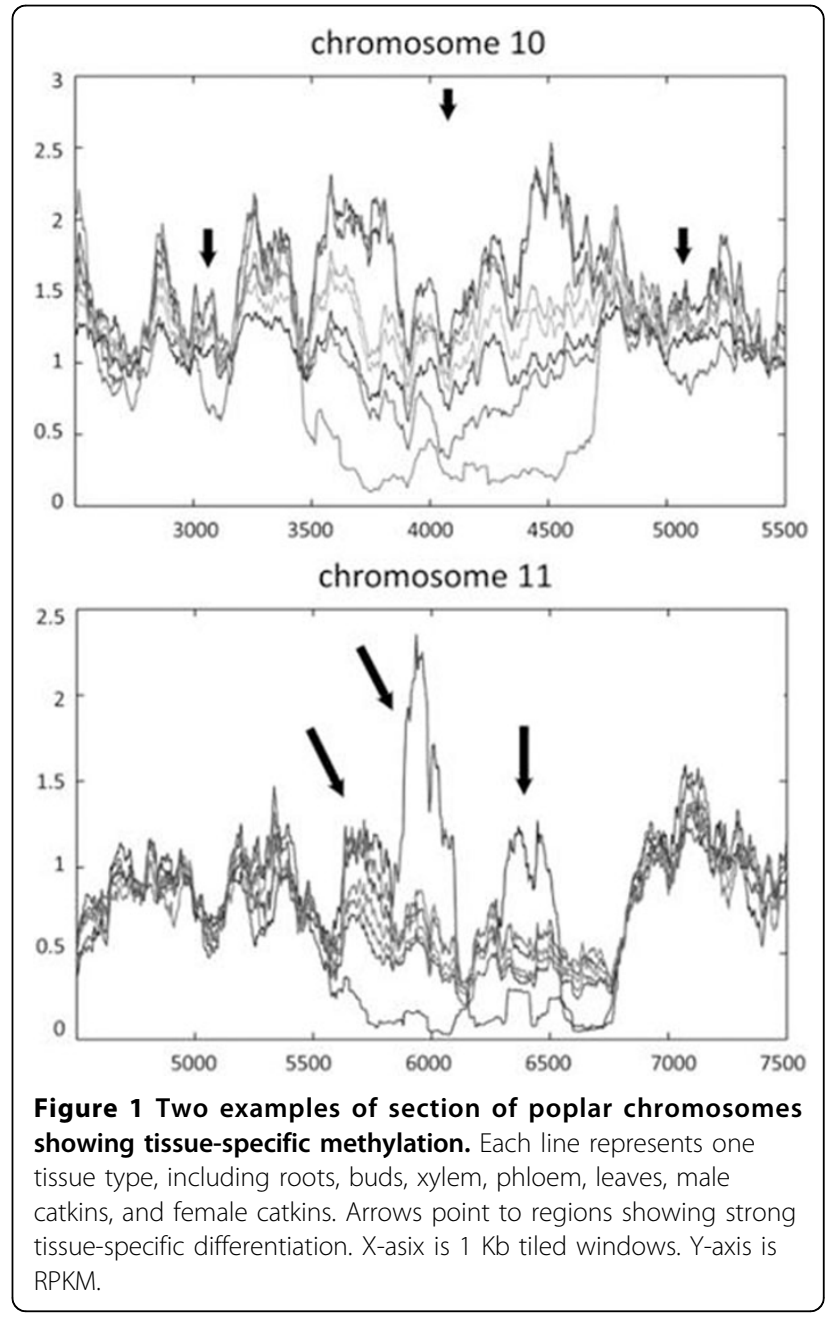

\footnotetext{
* Correspondence: Steve.Strauss@oregonstate.edu

${ }^{6}$ Department of Forest Ecosystems and Society, Center for Genome Research and Biocomputing, Oregon State University, Corvallis, OR 97331, USA

Full list of author information is available at the end of the article
}

(c) 2011 Vining et al; licensee BioMed Central Ltd. This is an open access article distributed under the terms of the Creative Commons Attribution License (http://creativecommons.org/licenses/by/2.0), which permits unrestricted use, distribution, and reproduction in any medium, provided the original work is properly cited. 
transposable element categories that were methylated in all other tissues were unmethylated in male catkins. We also analyzed the association of methylation intensity to gene expression data from an existing microarray study of the same tissues. At a whole genome scale, both promoter-methylated and body-methylated genes had lower expression than unmethylated genes. We will report on our continued studies of tissue methylation/expression relationships.

We have developed a customized genome browser (Gbrowse version 1.69), compatible with the most recent (v2.2) P. trichocarpa genome assembly, at which our data can be explored: http://poplar.cgrb.oregonstate.edu.

\section{Author details}

'Department of Forest Ecosystems and Society, Oregon State University, Corvallis, OR 97331, USA. ${ }^{2}$ Molecular and Cellular Biology Program, Dept. of Biochemistry and Biophysics, Center for Genome Research and

Biocomputing, Oregon State University, Corvallis, OR 97331, USA. ${ }^{3}$ Department of Botany and Plant Pathology, Center for Genome Research and Biocomputing, Oregon State University, Corvallis, OR 97331, USA. ${ }^{4}$ Deptartment of Molecular, Cell and Developmental Biology, University of California, Los Angeles, Los Angeles, CA, 90024, USA. ${ }^{5}$ Dept. of Biochemistry and Biophysics, Center for Genome Research and Biocomputing, Oregon State University, Corvallis, OR 97331, USA. 'Department of Forest Ecosystems and Society, Center for Genome Research and Biocomputing, Oregon State University, Corvallis, OR 97331, USA.

Published: 13 September 2011

doi:10.1186/1753-6561-5-S7-P177

Cite this article as: Vining et al:: Developmental variation in DNA methylation in poplar (Populus trichocarpa). BMC Proceedings 20115 (Suppl 7):P177.

\section{Submit your next manuscript to BioMed Central} and take full advantage of:

- Convenient online submission

- Thorough peer review

- No space constraints or color figure charges

- Immediate publication on acceptance

- Inclusion in PubMed, CAS, Scopus and Google Scholar

- Research which is freely available for redistribution

Submit your manuscript at www.biomedcentral.com/submit
C Biomed Central 